Metodički obzori 6(2011)3

Professional article

UDK: 372.41/.45:004

Received: 16. 10. 2010.

\title{
NEW MEDIA AND TEACHING ELEMENTARY READING EDUCATIONAL PROGRAMS FOR LEARNING TO READ AND WRITE
}

\author{
Jelena Marić, graduate teacher \\ Primary school "Braća Ribar", Sisak (Croatia) \\ e-mail: jelena.maricsk@gmail.com
}

\begin{abstract}
Initial reading and writing for most students is a huge shock. After the period of games and drawing, suddenly they have a numerous academic appointments. In recent years an increasing number of children who are coming to school already know how to read and write - some children were taught by parents, some learnt by watching TV, some with educational software.

This paper is interested in the quality of such software and trying to find an answer to a simple question - could we create such software to facilitate the child beginner troubles with the initial reading and writing?

Key words: educational software, the initial reading and writing through the alphabet game, $e$ - spelling, letters and numbers, school clash - the fight knowledge Jezikomjer
\end{abstract}

\section{Introduction}

In the last ten years, another educational problem appeared amongst others: children do not want to read the writing that was recommended for them by the Ministry of Science and Technology. Interviews, methods of punishment or rewards, persuasion, motivation, often do not produce results. Students who "love to read" or have developed the habit of reading regularly read books for school, and students who "do not like" do not want to read or, more often do not read the piece offered to them.

When we ask children, who do not like to read, why they did not read the book, we get different answers like: "I didn't feel like it?", "Cartoons are more interesting", "I was playing games." or "I do not like to read." These answers were given to me by teachers and students.

A new challenge is in front of a modern teacher: How the book, which this year reaches the age of 557 years, can be embraced by the modern student and the requirements of modern teaching? 


\section{New Media in the Croatian language}

Recent years, the Croatian market is flooded by the various educational programs - they were first in English and then in Croatian language. They are mainly collection of simple programs for training, which are characterised by learning in small steps and isolated tasks. These programs are mainly for children of preschool and early school age, and their goal is to bring closer and in a fun way reading and writing, to alleviate the initial shock.

\section{Before school (preschool age)}

Interactive DVD: The ABC of the game (2010). Artmedia, Varaždin

The DVD is recommended for children aged 2-6 years. Interactive DVD gives through watching videos, using the remote control, chance to actively participate in the learning process, to repeat particular scenes, to seek answers and that the child on its own determines the rhythm of learning based on his or her ability to concentrate, auditive and visual perception and already acquired knowledge.

The DVD was made on the principle of image cards (flash cards) and allows easier learning and memory linking images and words (mnemonics).

Alphabet through the game is an interactive DVD video that helps children to master the basic knowledge of letters in kindergarten, pre-schools, and even in first grade.

This interactive DVD is based on picture cards (flash cards), and it was made as a support for letters learning with children who are learning the letters for the first time, children who have problems with concentration, and children who have difficulties in pronunciation of certain sounds.

\section{What's on the DVD?}

$1^{\text {st }}$ I l learn letters

$2^{\text {nd }}$ : Reading

$3^{\text {rd }}:$ When I learn the letters / Games

$4^{\text {th: }}:$ Letter Search

$5^{\text {th }}:$ Word Search

\section{1st I learn letters}

DVD has a sound base - female voice reads the first letter, then words. First, a yellow letter appears in front of the child and then comes the picture which can be associated with a specific letter. The image is located in the middle of the screen, the letter above it and a term written below the image.

The things that are not so good are the choices of terms and images. For example, if we want our children to adopt a standard, to stop babble, then the educational software should not contain terms such as koka. Furthermore, when a letter I is introduced to a child a picture of a teddy bear appears, the child should say A TOY (although a child at the age of 2 or 3 will intuitively say that this is a bear). When your child shows the letter 
$\mathbf{L}$, the image that appears is a picture of fawn. It is hard to believe that the child at the age of six has a word fawn in his vocabulary.

There are several dubious notions and images:

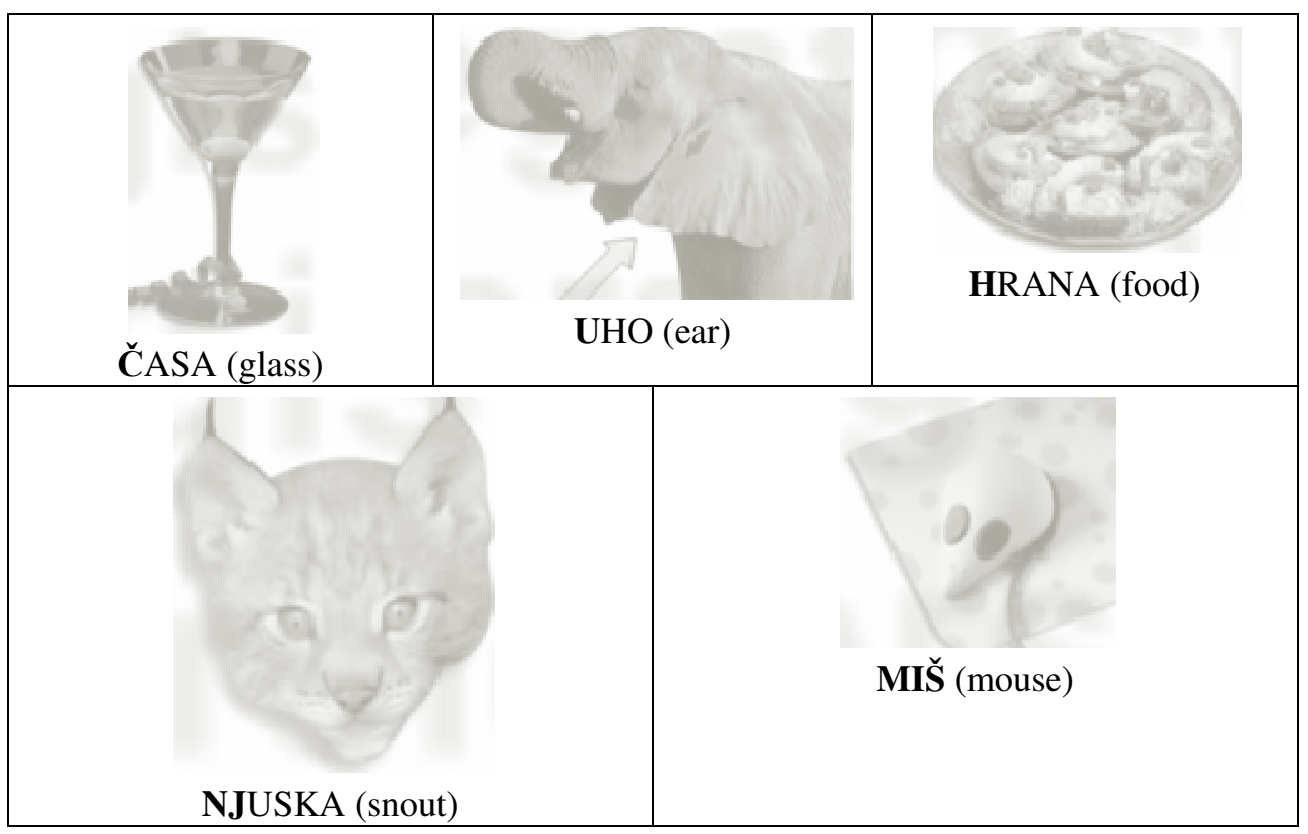

In addition, everything turns and hops on the screen in front of the child and remains very short.

\section{2nd Reading}

On this DVD - the children are learning how to read: the word appears at the top of the screen (e.g. AUTO), then the picture appears very quickly (car) and a letter by letter is read to the child (A_U_T_O). I think it would be more useful to show a picture after the spelling - this way a child is forced to follow the letters on the screen, not to make conclusions based on the pictures. Also, there is only a certain vocabulary (car, banana, flower, brush, cup, camel, jeep, students, screen, hair, mushroom, helicopter, toys, strawberries, cubes, swan, ladders, mouse, orange, muzzle, wasps the package, fish, watch, shell, top, ears, wolf, rabbit, frog) and it is constantly repeated. After some time the child will know everything by heart, although he must "read."

\section{3rd When I learn to read}

There is song in this section that shows what a boy would be able to do when he learns to read. While a person is reading a poem, the words that are read become red. Unread remain blue. The song can be read very quickly so to keep track, the child must already be a proficient reader. 


\section{GAMES}

\section{4th Letter $\underline{\text { Search }}$}

An image is displayed before a child (e.g. dog). Then the child sees the following: - AS, and below letters D and P. The child should conclude that the missing letter is $\mathrm{P}$ (AS). If the answer is correct Bravo! appears on the screen, accompanied by applause, and if the answer is incorrect, the wrong letter will be struck and the narrator will say the solution.

The first letter is missing at the beginning of this exercise, then one of the letters in the middle and finally the last letter.

\section{5th Word Search}

The child should find a certain word that starts with a particular letter. For example, the letter $\mathrm{S}$ is written at the top of the screen. The picture of a dog (PAS) and an ice-cream (SLADOLED) appears at the bottom of the screen. If the child answers correctly, ice cream will be rounded up and only then the word ice-cream will appear. Again it all depends on the child's experience with pictures. Everything is too tied to the picture, not the word.

e-Spelling, Nakladni Centar, Zagreb, 2005.

e - Spelling is the educational program adjusted to children aged 3-7. The program was created as collaboration between educators and psychologists. By using espelling children acquire basic knowledge on the computer and they enrich their vocabulary and improve pronunciation.

\section{What is on the CD - ROM?}

$1^{\text {st }}$ : Alphabet

$2^{\text {nd }}:$ Game for beginners

$3^{\text {rd }}$ : Which letter is missing

$4^{\text {th }}:$ Just for excellent students

Robot Spelled (SLOVKO) leads us through the program (with a very unusual electronic voice). If you hesitate, he urges you (I'm waiting, Wake up).

\section{1st Alphabet}

The letters of the alphabet are in front of the child. The child only has to choose the letter he wants and the robot will pronounce it.

\section{2nd Game for beginners}

The child should recognise which letter the term in the picture begins with. The award is an ice cream. The child should collect five of them. If the child does not know the solution, e-Spelling reads the term and says which letter is missing. The concepts are simple, understandable to children; the images are clear and show exactly what you need.

When the child collects five ice creams, e-Spelling commends him (This is for A) and asks if he still wants to play. If the child chooses that he or she will continue (green checkmark), he or she gets a new series of five tasks. If the child does not want to continue the game (red X), he or she can choose a new game at the main menu. 


\section{3rd Which letter is missing}

In this game the child also needs to collect five ice creams, and the aim is to identify which letter is missing in a word.

\section{4th Just for excellent students}

The last game is the toughest game on CD. The letters are mixed, and the child needs to write the correct word. There is also a picture that represents the term and after some time the word is read by e-Spelling.

e - Spelling is a simple program for the initial reading and writing and precisely because of its simplicity is so special and good. There is no too much background noise, as well as too many "special effects" that could disturb child's concentration.

Initially reading and writing can really be easier with this program. The concepts are not repeated so the child can go and play the same game for a few times, without learning them by heart. e-Spelling hops in only when the child makes a mistake. The child is allowed to go through the game alone.

When your child solves all the tasks e-Spelling rewards it with A and waves good-bye to his student.

The only drawback of this program is the fact that the child learns to read printed letters and the questions at the end of the game (Would you like to continue playing?) is written in write letters, so it is difficult for the child to understand what e-Spelling is asking him. On the other hand, it is preferable that a parent is with a child while the child is working on the computer.

Letters and numbers, Compmedia, Zagreb, 2008.

Games with letters, words and numbers are a set of activities full of surprises and interactive games with letters, numbers and games that enrich the dictionary. More different levels of difficulty will allow children to play a pace that suits them.

What is on the CD - ROM?

$1^{\text {st }}:$ Letters and numbers

$2^{\text {nd }}:$ Star

$3^{\text {rd }}:$ Packman

$4^{\text {th }}:$ Connect the term with an image

5 th Connect the dots in a specific order

This is a software that has occurred in America and here are just literally translated. This is particularly obvious in the first game.

\section{1st The letters and numbers}

Caterpillar is sleeping for a long time, and must be awakened. Squares with colours are on the left side of her body, and the letters are at the top of the page. Caterpillar dreams about letters in color and a child should open the appropriate field. When all the fields are opened, a mixed picture appears that should to be properly set.

There are two very important details that can be a problem. First, our publishers has translated only spoken part (explanation), but not complete tasks, so our 
preschoolers need to know letters $\mathrm{q}, \mathrm{w}, \mathrm{x}$ and $\mathrm{y}$. It would be much more useful to "activate" our palatals. Another problematic detail is that the caterpillar whilst sleeping snores, which after a few minutes begins to annoy, which affects concentration of a child aged 4-7.

\section{2nd Star}

The aim of this game is to leave the smallest possible number of balls. You click with your mouse on the ball, and skip the ball to come to an empty place. This way the ball we have skipped will disappear.

\section{3rd Packman}

The third game is another version of the popular game Packman. The term cat (mačka) is written in the middle of the screen. It is necessary to bring the fish to the real drawing of a cat (mačka), and while doing that to swallow as many small dots as possible and not to be eaten by the red fish.

\section{4th Connect the term with an image}

This game has three levels - from easy to difficult. The image of an animal is in the bubble; a child needs to determine which image matches the description on the screen. The first level has one description, the second two and the third offers a description of the animal and what the animals do.

\section{Connect the dots}

Each dot is assigned a number from 1 to 11 . It is necessary to connect the dots in the exact sequence of numbers 1-11 in order to get some pictures.

In addition to the problematic letters in the first game, this software has a few flaws. Tasks are poorly explained and in some cases a significant effort is needed in order to understand what exactly you are looking for. There are also very questionable terms that a child of four years would know. In the fourth game- third level terms like this galloping, shell, slow, claws, webbed feet, tails, nibbling etc are used. A child should link galloping to zebra, shell and slow to tortoise, the claws to cancer, webbed feet to duck and a tail and nibbling to mouse.

Tasks with letters and words are badly done, there is too much background sounds and everything is very dark (dark background and dark characters). This software can entertain children (especially the part with puzzles and colouring books), but I doubt it would be of any great help with learning to read.

Now we know how to read - let's learn!

School shock - the fight of knowledge, 32 bits and Croatia Records, 2005.

School Shock is the same as the old Shock (the first Croatian computer game) with questions based on the school program. A total of six titles cover the material from 3 to 8 grades, with a total of 25,066 questions. Shock is social game, for two or four players and the best is when you beat someone who sits next to you, but there is also a 100 level maze for one player that will provide plenty of challenges, when the game company has not yet arrived. Each Shock has a program for writing questions, so you can add your own questions, after you write them on this site, you can transfer them into a format that is understandable to your collision. Questions can be used for your own 
use or you can download them for all those who play Shock. Shock has no set lifetime; the same CD will be usable in the following years (until the new version of Windows will be compatible with XP). After all, the Shock is here for 12 years, few games last so long. And probably most important, Shock is a real game, not a machine for learning by heart. The challenge is to solve the problem, be better and outwit opponents; the questions are just a tool for achieving this goal. Learning can certainly be fun.

Through these quiz elementary school students compare their knowledge with their parents, and there is an option of playing online. It supports up to 4 players playing on one computer or network, and almost everything from the number of players and time to answer the question, panel size and number of figures in the game can be adjusted. Questions include the third grade curriculum and are divided chronologically from the repetition of the previous grade and the four quarters (with teaching units).

The questions were consistent with the curriculum and educational standards. When textbooks, curricula, etc. change, Shock needs only to be refreshed with new questions.

The big advantage of this software is that you can choose which area you want to examine: science, mathematics or Croatian language. If the teacher finds questions too hard or too easy, he or she can add new questions, because every teacher knows the strengths and weaknesses of his/her students.

Shock is much better programmed than similar software in our market - Fun and Games (Učilica). While Fun and Games are richer with multimedia and more colourful, Shock is more based on "relationships". A child knows how much time s/he has, and that knowledge and speed are most important, but there is no virtual teacher who blames children for incorrect answers. Also, Shock can be played by 4 players and Učilica cannot.

\section{Jezikomjer - a guide for avoiding common errors in the standard Croatian language, J. Nikić - Ivanisevic, N. Iris, Z. Zlatar, Croma Co. Stobreč}

The content of this media release, which consists of books and two attached audio CDs, follows the popular television show Jezikomjer. In a brief and easily acceptable form, the speakers of Croatian language are warned of the commonly made mistakes in everyday life (e.g. personal and public, business and media communication).

Speech errors are written in alphabetical order and can be found in the attached text and sound issues and are followed by professional, brief and understandable explanation.

This CD is rich in multimedia content. These are audio recordings of what is explained in the book. This is indeed a laudable project, which is worth mentioning, although it has nothing to do with the software for the initial reading and writing. 


\section{Conclusion}

One of the fundamental issues of today's digital age is how to make working on the computer friendlier to a child, to entertain him, but also to teach him/her something? There is a handful of educational software on the market that can help us to learn how to read, write in mathematics and the world around us.

Personally, I agree with those who are against such an imitation of the reality. Although, informatics is my profession, as well as the area that I love and am trying to promote, I think that a child must learn about the world around in the world around him/her.

Imagine the following: Ariel received an educational software for learning to read as a gift. Ariel has independently learned to run the software and decided to learn to read. Ariel looks and sees that the letters turn, leap to create a certain words. She manages to identify all the letters, maybe even read a few words. Ariel starts going to school, she is proud of her knowledge of all the letters. But what happens?

Letters are not jumping and not turning out in the school. They stand. The book does not list by itself. Notebooks do not sing while she is writing in them. The letters are not written by a simple click of the mouse - it is necessary to invest much more effort. The thing that is not developed at Ariel is fine graphomotoric.

Ariel is shocked. The parents have experienced the shock and are probably angry at the teacher because they have purchased educational software!

The situation will get even more difficult if the parents have completely digitized Ariel's reality. Does she draw with real crayons or in MS Paint? Does she learn about the world by playing with other children, or staring at the computer screen?

Computers certainly have many benefits and they can be used to facilitate learning to children. There is one very important question; does my generation who learned to read letters from the book know less than today's children who learn them from the screen?

After all, when a child who has dyslexia says that his letters are dancing before his eyes and turn around and look strange we detected it as a problem. Why then do parents buy the software on which the letters look strange, move and sing?

Contemporary school is criticised for its insisting on practice. But, practicing of reading and writing, and later learning how to spell, can be rehearsed only with practice. Learning how to read and practicing how to write it is necessary, it should not be funny! Educational software can be a good help, but not the only means of learning.

How to prepare children for learning how to read? Children must be well prepared by parents (and a no less essential grandmother) in the following way:

- discuss everything with your child and give him a chance to talk

- read and learn songs with rhyming

- read picture books so that each word is followed by a finger

- adults should read and write to children and include them in these activities

- visit the library with your child

- circle child with picture books, books and material for writing and drawing

- allow the child to list picture books by itself. 
The child can learn to read and write through game - by playing with parents and peers, not with a machine without emotions. A child needs to understand that the books are meant to be read and the paper is used to write words on it. After all, computers and its accessories (such as a mouse) are not designed for a child - they are designed for adult hands.

A child's arm must be accustomed to fine motor skills, and it will get accustomed to it by holding a pencil in its hand while drawing and writing. Also, letters should be learnt where they have the most sense - in the books. These way children will enjoy reading when they grow up.

\section{Bibliography}

Armstrong, T. (2006), Multiple intelligence in the classroom, Zagreb, Educa

Cvetković-Lay, J., Sekulic-Majurec, A., (1998), It's gifted - what to do? Zagreb, Alinea

Čudina-Obradovic, M., (2000), When the princess says prince - the psychological foundations of teaching reading and writing, Zagreb, Korak po korak

Mayer, RE, Moreno R. (2001.) Meaningful Learning from Words and Pictures: An Educational Psychology of Multimedia. http://www.unm.edu/ moreno / pdfs / chi.pdf (18 9th 2009.)

Moomaw, S., Hieronymus, B. (2008), Games of reading and writing, Buševec, Achievement

Hubby, V., Rodek, S. (1987), Computers in transforming schools, Zagreb: Školska knjiga

Panian, Ž. (2005), English-Croatian IT encyclopedic dictionary, Zagreb, Jutarnji list

Reeves, TC (1998), The Impact of Media and Technology in Schools, The University of Georgia. http://it.coe.uga.edu/ treeves/edit6900/BertelsmannReeves98.pdf (19th 9th 2009.)

Rosandić, D. (2005): Methods of literary education, Zagreb, School Books

Sherwoo d, RD (1986) Model of Computer Use in School Settings, http://www.eric.ed.gov/ ERICWebPortal/custom/portlets/recordDetails/detailmini.jsp?_nfpb=true\&_\&ERICExtSearch_Search Value_0=ED262753\&ERICExtSearch_SearchType_0=no\&accno=ED262753 (179th 2009.)

Tomas, S., (2007), Learning and Teaching of pupils in primary education with the help of tutoring systems (thesis), Faculty of Philosophy, University of Zagreb. http://bib.irb.hr/datoteka/ 209652.TomasS.pdf (18 9th 2009.)

Velički, V., (2005), Literary works in multimedia processing and reception of interactive text (for example from children's literature), (unpublished doctoral thesis), Faculty of Philosophy, University of Zagreb

Young People's Reading at the End of the Century: A Summary of the Children's Literature Research Centre Survey of Young People's Reading Habits "Youth Library Review 22 (Autumn, 1996.): 6-15

Staige r, RC: (1990), Developing the Reading Habit in Children, Literacy Lessons. Geneva: International Bureau of Education, ERIC ED 321062 11th 2009).

http://www.ffos.hr/katedre/knjiznicarstvo/projekti/?cont=istrazivanje_citateljskih_interesa (15

http://knjiga.hr/08.asp?mjesec=\&ID=5504 (15 11th 2009).

http://www.matica.hr/kolo/kolo2008_3.nsf/AllWebDocs/Gdje_su_nestali_mladi_koji_citaju_ (15 11th 2009).

http://www.vjesnik.com/html/2006/10/24/Clanak.asp?r=tem\&c=3 (15 11th 2009).

http://dzs.ffzg.hr/text/sabolovic-krajina_1993.htm (15 11th 2009). 
Metodički obzori 6(2011)3

Stručni rad

UDK: 372.41/.45:004

Primljeno: 16. 10. 2010.

\section{NOVI MEDIJI I NASTAVA POČETNOGA ČITANJA I PISANJA EDUKATIVNI PROGRAMI ZA UČENJE ČITANJA I PISANJA}

Jelena Marić, dipl. učiteljica

Osnovna škola Braća Ribar u Sisku (Hrvatska) e-mail: jelena.maricsk@gmail.com

\section{Sa žetak}

Početno čitanje i pisanje za većinu je učenika ogroman šok. Nakon igre i crtanja, iznenada dolaze brojne školske obveze. U posljednjih nekoliko godina sve veći broj djece koja dolaze u školu i već znaju čitati i pisati - neka djeca su naučila uz roditelje, neka gledajući TV, neka uz obrazovni softver.

Ovaj rad se bavi kvalitetom takvih softvera i pokušava pronaći odgovor na jednostavno pitanje - možemo li stvoriti takav softver kako bi se djetetu olakšalo početno učenje čitanja i pisanja?

Ključne riječi: edukativni softveri, početno učenje čitanje i pisanja, Abeceda kroz igru, e-slovarica, Slova i brojevi, Školski sraz, Jezikomjer 